\title{
Steering clear of politics: local virtues in Helsinki's design activism
}

\author{
Eeva Berglund ${ }^{1}$ \\ Independent scholar, Helsinki, Finland
}

\begin{abstract}
Practical projects around the world are exploring and prefiguring ecologically feasible futures. The ideas informing these initiatives are familiar from degrowth discourses. But particularly where activists hail from the professional middle-classes of wealthy cities - architects, designers and other 'creatives' in Helsinki for example - they risk being dismissed by the media as well as by academics as vacuous life-style experimenters. Looking at Finland, the sense that this activity is not truly political or transformative can be further enhanced by activists' own reluctance to enter into explicitly political debate and their preference for discussing futures in the neutral language of science. Connecting today's situation to precursors in the 1960s, however, we can see how these local projects are embedded in local political culture, including a Finnish tendency to play up scientific rationality as a tool for managing collective affairs. This contrast with many other degrowth discourses shows the significance of local histories in influencing the space available for people to work out alternatives to the status quo.
\end{abstract}

Keywords: social movements; Finland; urban/DIY activism; design

\section{Résumé}

Dans le monde entier, des projets pratiques essayent d'explorer et de préfigurer un avenir écologiquement viable. Les idées informant ces initiatives sont familières aux discours de décroissance. Mais en particulier lorsque les activistes viennent de classes moyennes professionnelles des villes riches - des architectes, des designers et d'autres créateurs à Helsinki, par exemple - ils risquent d'être rejetées par les médias, ainsi que par les académiques, jugées comme venant des expérimentateurs de style de vie vide. En prenant la Finlande comme exemple, le sens que cette activité n'est ni politique ni transformative peut être renforcée par la réticence des activistes à d'entrer dans le débat politique ainsi que par leur préférence de discuter d'un avenir dans le langage neutre de la science. En connectant l'actuelle situation à celle des précurseurs des années 1960, nous pouvons, cependant, voir comment ces projets locaux sont intégraux à la culture politique locale, y compris la tendance finlandaise à exagérer la rationalité scientifique comme un outil de la gestion des affaires collectives. Ce contraste avec d'autres discours de décroissance montre l'importance des histoires locales pour influencer l'espace disponible qui permettent aux gens d'inventer d'autres possibles statu quo.

Mot clés: mouvements sociaux, Finlande, activisme / bricolage urbain, conception

\section{Resumen}

Diversos proyectos prácticos en el mundo están explorando y prefigurando futuros ecológicamente viables. Las ideas informando estas iniciativas son reconocidas en los discursos acerca del decrecimiento. Pero cuando los activistas proceden de una clase media profesional y, en particular, de las ciudades ricas - por ejemplo los arquitectos, diseñadores y otros "creativos" en Helsinki-ellos corren el riesgo de ser rechazados por los medios de comunicación y por los académicos como experimentadores superficiales, jugando con estilos de vida. En cuanto a Finlandia, la sensación de que esta actividad no es transformativa ni verdaderamente política puede ser fortalecida por la resistencia de los activistas a entablar un debate político y por su preferencia de usar el idioma neutral de la ciencia para discutir acerca de los futuros. Sin embargo, al conectar esta situación a sus precursoras en los sesentas, podemos ver como estos proyectos locales están

\footnotetext{
1 Dr. Eeva Berglund, Independent scholar, Helsinki, Finland. Email: eeva.berglund "at" helsinki.fi. Web: https://eevabee.wordpress.com. Thanks to all the people in Helsinki who have lived with my questioning over the years, including the Suomenlinna 1968 interviewees and Jukka Noponen, and to Elina Alatalo, Susan Paulson and Lisa Gezon. This is the eight article in Lisa L. Gezon and Susan Paulson (eds.) 2017. "Degrowth, culture and power", Special Section of the Journal of Political Ecology, 24: 425-466.
} 
incrustados en la cultura política local, esto incluye una tendencia finlandesa a reproducir la racionalidad científica como una herramienta para gestionar asuntos colectivos. El contraste con otros discursos de decrecimiento presenta la importancia de las historias locales para influir en los espacios disponibles para elaborar alternativas al estatus quo.

Palabras clave: movimientos sociales, Finlandia; activismo / DIY urbana, diseño

\section{Designing better futures in 'tiny social movements'}

My window onto degrowth is the mostly unspectacular practical work of small groups of people who are prefiguring ecologically feasible futures and popularizing alternative, if vague, visions of a future normality outside the growth paradigm. All around the world people are seeking to make change through decentralized activities that go by many names: DIY-urbanism, urban experimentation, tactical urbanism, prototyping, urban commoning, design activism and so on. More and more municipalities encourage such citizen-directed and world-improving projects, but to assume that this activity is about seeking alternatives to the politics of economic growth would be misleading. Its role in wider socio-economic structures is always context-specific and often contradictory. The media and even academics have dismissed it as utopian. From the point of view of many of those involved, however, what is utopian (or at least outdated) is the mainstream habit of seeing economic growth and so-called consumer confidence as indications of progress. The future, they feel, cannot possibly recapitulate the resource-destructive present and recent past.

The focus here is on Helsinki, where degrowth is one strand within a family of ideas gaining traction as capitalist normality persistently falls prey to multiple crises and manifold critiques. Working at small scales, more focused on socio-technical change than on political ideology or economic critique - let alone violent revolution - Helsinki's diffuse and sometimes tentative projects do not quite add up to a social movement as conventionally defined, but they are, to borrow the words of activist and writer Pauliina Seppälä to whom I return below, recognizable as "tiny social movements" (Seppälä 2012). She characterizes these as born of "random" ideas often built up with the help of social media but picking up on current social issues "already out there." Articulating "emotions and positions" around these, participation offers a "medium with which to promote social and cultural change" (Seppälä 2012: 71). I see this voluntary effort less as resistance than as survival-oriented, understood in the broadest terms. It is an insistent yet sometimes complicated imperative to "do something," what Gwynn Williams has dubbed the "imperative of action" (Williams 2008: 72, quoted in Demmer and Hummel 2016) so familiar to ethnographers of socio-ecological movements.

\section{Political tensions of middle-classness}

Helsinki's tiny social movements develop alongside ordinary urban life, often among people who are not the most vulnerable or marginalized. They can be seen as the political descendants of Green critics who, for decades, have protested against exhausting environmental goods, but more than their precursors, current actors are also frustrated with the exhaustion and injustices of work life (Koivulaakso et al. 2010, see also Brennan 2000). The result is a critique of economic growth that is recognizably of the wealthy North and sometimes explicitly informed by degrowth thinking (Demaria et al. 2013) but is often vague about political purposes. A local peculiarity that I shall highlight is Finnish activists' enthusiasm for science. I have even heard the claim, made with no sense of irony, that we Finns are better placed than most to access truth through science. Meanwhile a style of critique does flourish that ridicules this discourse of scientific hubris, as well its frequent corollary, the notion that Finland is somehow less vulnerable to technological risks than other places. The critique is often made through $\operatorname{art}^{2}$ and popular music, but also in writing (in English see Kalliala et al. 2011). Of course, activism in Helsinki is far from homogenous. Many groups present themselves as radical, some clearly subscribe to techno-fixes that are compatible with green growth while

\footnotetext{
${ }^{2}$ Return of the atom, the documentary film by Mika Taanila and Jussi Eerola released in 2015, is an excellent example, training a very ethnographic and nuanced lens on the nuclear community of Eurajoki, site of the first nuclear power plant to be commissioned in the west since Chernobyl.
} 
others vehemently oppose these. In any case people are often articulate about the shortcomings of other groups' or, indeed, their own, politics.

However, as in some recent waves of protest around the world that have been criticized for pragmatism and rejecting explicit ideological programs (Taylor 2013), Helsinki's activists are sometimes dismissed (or worse) as vacuous life-style experimenters. Disproportionate numbers of those involved have design and architectural backgrounds, and they easily conform to the image of the post-industrial economy's labor force, the "creatives." And although activists in Helsinki are often celebrated for their initiative, both in the media and in academia, there have been suggestions that their progressive-sounding rhetoric masks what are actually the regressive politics of people who can afford to down-shift, to embrace post-material values or toy with lower-class tastes, and so on. In the pejorative populist speech that has increased in Finland in recent years, activism becomes associated with naïve world-improving efforts and a putatively unnatural tolerance for (cultural) difference. Such perspectives build on and contribute to constructs such as a "left-Green bubble" or stereotypical "hipsters." Critiques (or outright dismissal) of activism thus range from hate speech that cannot be reprinted here to seminar-friendly attentiveness to the ways neoliberalism co-opts would-be protest (comp. Guthman 2008; McClintock 2014). Interestingly, these latter critiques are rarely committed to print in Finland, researchers perhaps being sensitive to the potential for misuse of their observations. ${ }^{3}$

From a North American point of view, but one that has salience in Finland as well, John Bellamy Foster has argued that "to pin an analysis of global sustainability on hopes of overturning an abstract 'growth society' is to lose all historical perspective and discard centuries of social science" (2011: 32). From an empirically grounded anthropological standpoint, I sympathize with that view, but I also consider it possible, even probable, that activists' critique of economic growth is meaningful and even impactful even when it is not underpinned by academic perspectives on history and social science. In that spirit, this essay emphasizes the importance of their simply acknowledging some of the difficult experiential problems associated with capitalism's basic growth impulse. However hazy on detail, that acknowledgement is central to the volunteer work I will describe. It may also be crucial to overcoming unsustainability. And, as an agenda, the ideology of growth is also vague (Martinez-Alier et al. 2010: 1746), and proposing alternatives to it will of necessity be full of ambiguity and vacillation as well as the more systematic but context-dependent dynamics I outline below.

The grassroots projects at issue in this text are disproportionately in the hands of people who appear to be capitalism's beneficiaries. Most of the activists considered here live in greater Helsinki and are Finnish or of other unmarked ("white") ethnicity. They can take for granted a developed welfare system and - despite growing inequality - a cultural milieu where indices of class or status rarely dominate social encounters as they easily do in the UK or the USA. Class as a relationship to capital, though debated in Finland (Bergholm and Bieler 2013), is then less significant here than class as access to education and an affinity with international online and offline networks of environmentalists. Moreover, as noted, the city administration wants to harness the know-how of local residents to help solve shared socio-environmental problems. ${ }^{4}$ To think of the phenomenon of grassroots activism primarily in terms of resistance then would be misleading; a more accurate gloss might be that it constitutes an effort simply to live better. The not dissimilar "ecologies of hope" practiced by people in far less fortunate circumstances that Rajan and Duncan have so approvingly treated in this journal (2013: 70) unfold in quite different life circumstances, yet they resemble those of Helsinki's middle classes in being rooted in a need to improve life here and now. I am thus bracketing out activists' "middle-classness" to make room for something other than accusations of inconsistency and hypocrisy, and to be analytical without discrediting their efforts. ${ }^{5}$

In the search for more livable futures, the political, cultural and material resources of those who are fortunate cannot be squandered. In documenting them I draw inspiration from sympathetic analyses of emerging contemporary political forms, which recognize the effervescence of experimental politics and the

\footnotetext{
${ }^{3}$ But see Berglund (2013).

${ }^{4}$ A good example is the research and development project by University of Helsinki Department of Social Research, http://kaupunkiaktivismi.wordpress.com.

${ }^{5}$ A very different but not incompatible analysis, inspired by David Graeber, might develop ways to avoid reducing culture to consumer behaviour or subjectivities to variants of homo neoliberalis (e.g. Graeber 2011).
} 
countless ways of opening up alternatives to neoliberal dogma as necessary if not sufficient to politics in fragile times (Connolly 2013; Mouffe 2013, see also this Special Section). Seeking to capture a nascent phenomenon, I will sketch out a type of activism that is self-consciously seeking to redesign normality design activism - and show how it has been shaped by local political culture.

\section{Practicality and materiality}

Very practical projects to construct alternative lifeways have been undertaken in intentional communities as well as within society at large, as people have worked toward practical and material alternatives to those offered - or fervently imposed - as part of the growth paradigm. Such activity has been strongly associated with the 1960s, particularly with the hippie counterculture of the San Francisco Bay Area (Boal et al. 2012; Castillo 2015) and more generally with Cold War era student radicalism in the USA. In ethos if not in name, though, "design activism" as practical critique has a venerable history beginning far before the 1960s. Industrial production and the emergence of industrial design inspired committed and practical-minded critics from their beginnings.

Yet in an age somewhat obsessed with design, it does have a rather contemporary ring. Design activism refers to creative and provocative repertoires of practical interventions that aim to temporarily disrupt habitual attitudes (Fuad-Luke 2009; Julier 2013; Thorpe 2012), whether by forcing passersby to actually take note of their surroundings or through long-term initiatives to realize a more just and sustainable world (Escobar 2012; Lockyer and Veteto 2013; Manzini 2015). Inherently mutable, design activism fuses questions of justice, the environment and unknown futures. It has strong echoes of interventionist art from decades past ("artivism") (Mouffe 2013) and it sometimes pays homage to the mid-twentieth-century Situationists who ridiculed the impoverished spectacle of modernism with their humorous driftings around Paris designed to be militantly pointless (Pinder 2005). Indeed, the drop outs and back-to-the land activists of that period were doing more than rebelling or even seeking the child within: they were making physical adjustments that aimed to rearrange the world to better suit vulnerable people and uncertain futures. A well known example are the variations on the geodesic dome, maverick engineer Richard Buckminster Fuller's curious-looking, nature-respecting alternative structure that symbolizes the design ethos of America's ecoutopianism (Castillo 2015; Gordon 2008; Sadler 2012). One example of countercultural homage to Fuller's dome was spotted in 2013, in a car park in central Helsinki, where, built by the art collective Pixelache, it served for a few days as a temporary sauna.

With their rejection of convention and their self-consciously weird architecture, America's 1960s drop-out experiments had mixed success, and they did not generally survive very long (Boal et al. 2012). In historical light their claims to radical emancipation from the destructiveness of the mainstream may appear hollow: despite their avowed appreciation of the limits of the planet and the foolhardiness of a growthoriented politics, it can be argued that the eco-activists themselves helped create the techno-optimism and even the technological and cultural transformations that later led to a new wave of capitalist expansion (Turner 2005).

This ambivalent legacy notwithstanding, North American "hippie modernism" (Castillo 2015) is certainly an inspirational and illuminating place to go to seek precursors for practical degrowth projects (e.g. Goodbun et al. 2012). But if the aim is to shed light on contemporary Finland, it would, however, be misleading to give too much weight to American culture, visible and influential though it has been. Green ideas have certainly travelled from the USA and made a difference to Northern European environmentalism. The 1962 milestone, Silent spring by Rachel Carson, was translated into Finnish as early as 1963 and later made an impact. However, as Tuomas Räsänen (2012) has shown, it was not the main catalyst for the rise of modern environmental thought in Finland as many still believe. Finnish environmentalism was far more rooted in exchanges with Swedish scientists, and with events closer to home such as the 1972 Stockholm Conference on the Human Environment. The shocking realization that at stake were the earth's life-support systems themselves came via locally felt and quite home-grown experiences of poisoning by chemicals, specifically in the Baltic Sea (Räsänen 2012: 173).

Similarly, although America's "countercultural bricoleurs" (Andrew Kirk, forthcoming, cited in Castillo 2015: n.p.) whom we can consider degrowth activists avant la lettre, have been significant in Finnish 
alternative politics, their ideas and practices evolved here in quite specific ways. Pixelache's dome-sauna and other expressions of interest in older forms of alternative technology in contemporary Helsinki show that the 1960s are in vogue. In fact, Richard Buckminster Fuller himself lectured to enthusiastic audiences of young Finns in the late 1960s about impending environmental catastrophe and about how good design would help avert it. In general, the tiny social movements, or the "countercultural bricolage" now forging new lifeways here are better seen as part of regional and local traditions of knowing and living than as a delayed copy-cat response to an abstract globalism. Connecting events in Helsinki in the 1960s to what is going on today, I suggest that alongside practical innovations, middle-class activism is also forging collective political identity by building on local values and virtues. In this case these include playing up scientific rationality while playing down politics.

\section{Design skills and activism}

In the decades since the late 1960s, environmentalist ideas have become part of a global middle-class culture and therefore, unsurprisingly, have come to accommodate contradictory impulses and politics (Scoones et al. 2015). In Europe's wealthier cities like Helsinki, it has long been assumed that in their own way everyone is an environmentalist. Design-activist projects undertaken in the name of transition to sustainability cannot be taken as necessarily radical (Berglund 2013). Still, the seeds of meaningful transformation may be there. At least the practices echo the characterization of degrowth offered by Demaria et al. (2013): a critique of the current development hegemony and sometimes of the unwarranted optimism inherent in the idea of 'green' growth. The idea of degrowth remains politically marginal in Finland, and verbalized radical economic critique is rare outside certain circles. ${ }^{6}$ Some groups do explicitly promote degrowth in their practical projects, on blogs and in pamphlets and books (http://www.degrowth.fi; Ulvila and Pasanen 2010; http://mustarinda.fi/en/association). Serge Latouche's and other international writings on reforming economics circulate (2009). An explicitly degrowth "scene" notwithstanding, most people in Helsinki's grassroots environmentalist networks, however, simply adopt a vague attitude of expecting or hoping for an end to growth-oriented capitalism.

What follows are four brief examples of tiny social movements with a degrowth sensibility and an often unspoken yet palpable desire to transition to a world beyond consumerism and economic growth. Their reach into the social fabric is impossible to quantify, but what is undeniable is that some projects no older than a few years are already having an impact on ways of life as well as ways of governing. Decentralized and at least notionally self-organizing, the groups I describe create synergies, enjoy visibility and increasing respect and they incite the interest of growing numbers of environmentally concerned people of many backgrounds.

\section{The Turntable}

The Turntable garden and kitchen (http://kaantopoyta.fi/info) is a hub of urban gardening and food (and other) activism tucked away in a nostalgic red-brick milieu of former railway buildings, actually very centrally located in Helsinki, but obscure to most. It has poignancy right now as just next door is a gigantic building site, where construction is expected to continue for over twenty years. The garden's origins lie in a small raised bed that was semi-clandestinely tended in the summer of 2009 by activists from the environmental organization Dodo, an agile and perpetually innovative environmental grouping with a strongly urban profile and membership of young and middle-aged, variously committed people. When it was formed in the 1990s, most environmental organizations in Finland were resolutely rural or non-urban in focus. In addition to its high-profile role in popularizing new forms of and rationales for urban gardening, Dodo has functioned as a consciousness-raising organization, and a producer of new expertise, with many active members drawing on their experiences to develop sustainability as a social and cultural project in paid jobs. Above all Dodo has popularized the do-it-yourself ethos by developing activities where members can enjoy the conviviality of like-minded people while "getting their hands dirty" (Latouche 2009: 42; Deriu

\footnotetext{
${ }^{6}$ In spring 2016 a book chapter about the commons and the "new economy" (Toivanen and Venäläinen 2015) was, however, awarded a respected non-fiction writing prize.
} 
2015). The urban garden and the greenhouse built in and around the old railway turntable in 2012 are obvious examples, but Dodo's repertoire ranges from reading groups to experiments in using solar or pedal power to charge personal devices, from taking over parking spaces for outdoor living rooms, to elaborate one-day festivals of ideas.

With a preference for avoiding party politics and experiencing what one might call a gently rebellious ambience, many of its active members live what look like paradoxical lives. Those who work or study in conventional ways are quite tangibly caught up in earth-destroying systems even as they investigate and promote post-oil ways of living. I have been involved with Dodo with various levels of intensity since 2009, including a year as a board member, and most recently, as a volunteer at the partly freegan café it runs on summer weekends at the Turntable.

\section{The Urban Co-operative Farm}

A second rather established example of a kind of degrowth initiative taking root is the Urban Cooperative Farm (http://ruokaosuuskunta.fi/english), run much like a Community Supported Agriculture venture on a rented field just outside Helsinki. Members buy a share as in any co-operative, professionals run the farm, but administration, field labor and promotional events to bring new recruits are undertaken by members themselves. The 180 households involved in 2015 could pick up a weekly harvest of seasonal, biodynamic produce at one of four distribution spaces around the city. It is a loose community of like-minded people who need not share in the co-op's conviviality, but are free to do so if they wish at work parties and at the annual harvest party. Research into alternative food provisioning and government efforts to support it indicates that people's desire to participate stems from similar motivations as elsewhere: decoupling from unsustainable food infrastructures, participating in a joint face-to-face co-operative venture, and protesting Finland's highly centralized food retail sector. ${ }^{7}$

\section{Cleaning Day}

Cleaning Day (discussed in Seppälä 2012) began as a Facebook group working out a way to help shift city residents' unwanted possessions somewhere and to someone who might still have a use for them, and thus prevent them ending up in landfill. Since its beginnings in 2012, Cleaning Day has become a citysupported festival of recycling, reusing and repurposing that puts unwanted "stuff" back into circulation. For some, this is a way to begin to develop a closed-loop economy explicitly inspired by degrowth economics.

Cleaning Day seems very established today, and the city administration, keen to promote its credentials as both environmentally sustainable and keeping up with the times, promotes it as a local festival of contemporary virtues. Notionally Cleaning Day is not organized by anyone but its participants, but the online platform and funds persist due to the efforts of Yhteismaa of Common Ground, a non-profit social enterprise organization where Pauliina Seppälä (to whom I am indebted for the concept of tiny social movements) is a key figure. The event has spread to other towns, where in addition to turning parks, streets and other shared spaces into flea-markets, it involves municipal services organizing for the collection of hard-to-dispose of waste items, and educating the public about waste. In that sense, like Dodo who are behind the Turntable, the initiators of Cleaning Day are engaged in the kind of theoretical-practical knowledge work that Ulrich Demmer and Agata Hummel describe in their article in this Section (2017).

\section{Hietsu Pavilion}

My final example concerns the refurbishing of an old building, Hietsun Paviljonki (Hietsu Pavilion), a venture that lies somewhere between DIY activism as critique and more conservative efforts that have been labelled NIMBY. Carried out by a local association, its moving forces - activists - included local retirees with ample social and other capital. I joined them myself at a point when it appeared that the city was about to tear down the much-loved beach pavilion designed in the 1930s by Helsinki's then chief architect. Contrary to public pronouncements, it was in good structural condition, and a rare example of early $20^{\text {th }}$

\footnotetext{
${ }^{7}$ In Finnish: http://proruokapiirit.fi/files/MitenPerustanRuokapiirin_2016.pdf
} 
century, high-quality wooden architecture (Figure 1). The prospect of demolition felt like city-sponsored vandalism and, since the building is near where I live and also holds memories, I supported, in an ad hoc manner, the campaign to refurbish it. Happily, the building has been saved and re-opened as workspace for "creatives" and a venue for local community groups. As a building, it embodies contrasting models of realism (or utopia): its wooden, relatively small structure allows incremental, small scale maintenance (Ylönen 2015) and an understanding of sustainability that contrasts sharply with the market-driven, high-technology and large-scale homogeneity and greenwashing typical of the Finnish construction industry. Others, wary of the considerable costs of building maintenance in northern climates and perhaps also of the administrative burden of running a community building, see the pavilion's refurbishment as an economically unsustainable and random whimsy driven by what they see as obsessive middle-class nostalgia. Perhaps critics see it as part of or at least related to what they see as the utopianism of the "Left-Green bubble" I mentioned above. In terms of municipal government however, since the successful refurbishment of the pavilion, whether through budgetary constraints or for other reasons, the administration has given cautious support to similar citizen-led acts of maintaining Helsinki's urban commons, natural and built, in other locations also.

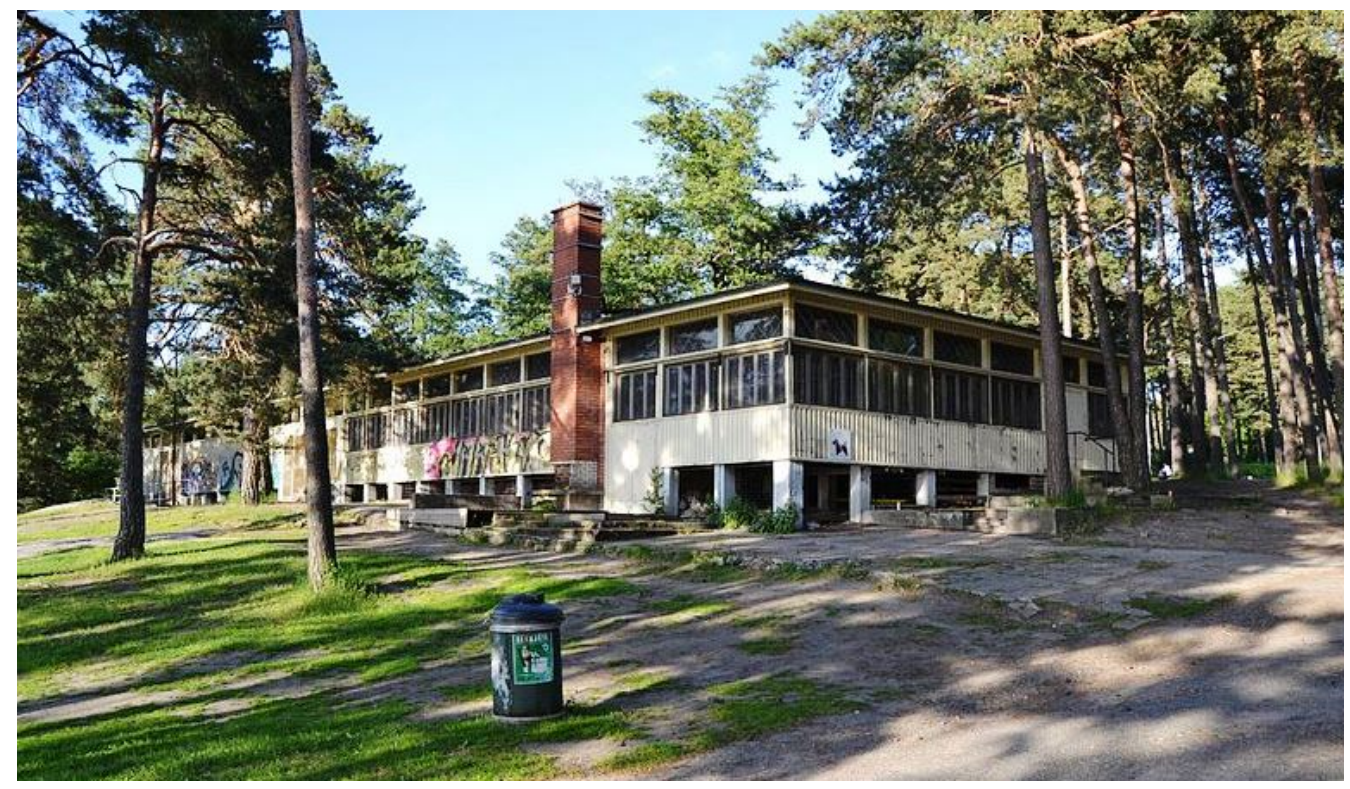

Figure 1: Hietarannan paviljonki (Hietsu Pavilion), 2012. Source: Wikipedia CC-BY.

However outsiders perceive them, in contrast to many of the other examples in this collection, all the cases I have mentioned downplay their ideological and political goals. What those involved do agree on, and are happy to acknowledge, are the rewards of their activism.

\section{Incipient dimensions of activism}

These examples outline a landscape of decentralized activity with features that are familiar from DIY initiatives around the world. When I ask participants why they engage in such activity, people tend to be vague about it, noting that it is fun, compulsive, makes them a better person and so on, or they joke about it. Rarely do they invoke degrowth. They do, though, make frequent reference to growth as a problem. Besides a concern for frugal use of limited resources, the examples also illustrate that there is an element of the carnevalesque. 
Collective effervescence and public performance are often noticeable elements of protest particularly where carnivals are part of local tradition but also where they are not. In seasonally changeable Finland, the summer has long been a time for reaffirming joint values and mutual dependency, a time for participating in festivals. Nevertheless, carnival can also be seen as a sanctioned way of keeping order and making money or both - not least as tourism (Szaniecki and Cocco 2015). As "circuses," the political deployment of spectacle has a very long urban history (though perhaps less so in Lutheran Finland than in Catholic Southern Europe), but tourist-friendly, innovation-oriented and above all, business-led agendas of urban competition made theatricality part of urban policy in the 1990s even in the Nordic world. In the year 2000 Helsinki was part of Europe's city of culture program. Being quirky and temporary, DIY-type urban projects were allowed to flourish by the city authorities. This also gave Helsinki residents new freedoms, and participants rediscovered forms of pleasure and beauty at a militantly human, anti-corporate, scale (Kohtala and Paterson 2015). Furthermore, by the 2010s, combining physical proximity with digital technology, Helsinki's activists had undertaken a range of self-organized collective actions in which a Finnish convention of collective work parties, talkoot, was also given renewed impetus: citizen-volunteering went from being either an oldfashioned or suspiciously "anarchist" practice to a recognized and delightfully home-grown twenty-firstcentury one.

Authorized public celebration was again prominent when Helsinki was World Design Capital (WDC) in 2012. Any analysis of this much-touted "new urban culture" must thus recognize its tensions (Berglund 2013, also McClintock 2014). Helsinki, like so many other city regions, has made innovation, creativity and culture explicit elements of city branding in international place promotion and sought to harness these to economic growth. This means that business-led municipal and government strategies can facilitate and support notionally protest-driven initiatives or ones set up specifically to seek alternatives. In fact, the kind of activism I describe flourishes where creativity and culture have been instrumentalized as part of urban policy (Berglund 2013; Cocco and Szaniecki 2015; Douglas 2014; Novy and Colomb 2013). And as under conditions of neoliberalism generally, critique risks losing its edge, "every critical gesture [...] quickly recuperated and neutralized by the forces of corporate capitalism" (Mouffe 2013: 85).

Behind Helsinki's bid to be design capital ${ }^{8}$ and the mostly small scale projects that ensued, there was a powerful lobby including government bodies at national and municipal level and many kinds of business interests. The novelty was that design was promoted as something that goes beyond the aesthetic realm. The WDC project sought to inspire and capture creativity as an environmental good, popularizing the notion that home-grown creativity and the human ability to make design choices were necessary to respond to "wicked" problems of global scope while at the same time revitalizing the nation's flagging exports. Increasingly, design was presented as transcending culture and norms and as such, it appeared much like the idea of engineering had in previous generations: a new variant of the techno-fix. The virtues of design and design thinking, and the notion that these would filter throughout society as scaled-up steps towards sustainability, were promoted. What were labeled nineteenth-century centralized government institutions, along with the state in general, came to appear as unfit or at least insufficient to manage the problems of the new millennium (e.g. Boyer et al. 2011). ${ }^{9}$ What emerged was a vague but always wholesome-sounding official and corporatesponsored narrative about Helsinki or Finland as a place that is somehow naturally home to quirky ventures, a place where global problems will find natural solutions.

There was resonance, even authenticity to the marketing-driven claims that Helsinki and Finland are technologically and architecturally progressive, and that Finland's forested and northern environment is somehow conducive to developing the solutions to the world's problems. The element of post-politicization (or de-politicization) typical of neoliberal discourse is, however, also evident (Swyngedouw 2010), with ecological urgency foreclosing political choice even as the discourse made it incumbent on everyone to take

\footnotetext{
${ }^{8}$ Cities make bids to the International Council of Societies of Industrial Design. http://www.icsid.org/programmes/wdc [accessed September 16 2016]

${ }^{9}$ Many different things were said, written and actually meant, the point is that a sense of political, green, revolution, was fostered. See e.g. Berglund (2013) for detail.
} 
initiative and to embrace a particular vision of sustainability. Alongside designing eco-friendly techno-social innovations, what was being designed was a new subjectivity, an eco-inflected good, self-motivating and ever-flexing entrepreneurial self. All this served to depoliticize the new change-making and render it harmless to profit making. To wit, in the context of increasingly entrepreneurial governance and state efforts to save on public expenditure, volunteer-based design activism can become part of rather than a protest against, the urge for economic growth.

This analysis also highlights the uncomfortable fact that the small interventions that activists have made are undoubtedly a drop in the ocean in terms of reducing ecological burdens. Refurbishing (not demolishing) a serviceable building, supporting local food production, selling (rather than throwing away) accumulated household clutter, harvesting useful plants from a few ten square meters of raised beds, generating enough pedal-power to run a sound system or charge some cell phones, or even adopting lowcarbon personal lifestyles such as avoiding meat and motorcars, makes little difference in the overall ecological footprint of anyone living in a modern, technology-intensive city like Helsinki. This contradiction throws into relief a more fundamental condition of our times, that people are caught up in the capitalist present, while at the same time being against and, in the case of activists, also beyond it (Chatterton and Pickerill 2010: 475). For activists this is unavoidable as well as unremarkable. This appears not to diminish motivation, and the practices I have described show no sign of disappearing in Helsinki or elsewhere. Sometimes they appear to merge with capital-intensive projects for sustainable futures, sometimes not. I suggest, borrowing Connolly's (2013) language, that they are energizing subterranean and potentially radical, if fragile, conceptions of what is right and good. As it prototypes future practices today, activism is bold and cautious at the same time. Significantly, what those involved do question is the possibility of everlasting capitalism. I shall show, however, that their discourses about this unfold in a local style that downplays political critique.

\section{Activist design now and in the 1960s}

\section{Changing the 'world depoliticized'}

Based on my observant participation in Helsinki, and acknowledging the multiple commitments and contradictory forces sustaining activism, I take participation in these initiatives to be both what activists say it is - a compulsion - and also an experiment in political organizing, although the idea is not much talked about and is sometimes even rejected. As a political project geared toward guiding collective life, one of its most interesting locally salient qualities, and a contrast with many of the other cases in this Special Section, is the un-cynical claim that all this activity is free of politics! The claim is most typical of the political elite, but it can be heard among activists also. Insofar as it scares the public into submitting unquestioningly to urgent action rather than reflection and deliberation. Thus activism itself fuels a depoliticizing ethos. Although certain activism builds on and elaborates moral arguments about human-environment relations, elsewhere it reaffirms the centrality and neutrality of scientific rationality.

Ignoring or avoiding politics is something that strong environmentalist agendas have long been accused of doing (e.g. Castells 1978). Science and Technology Studies (STS) in the last three decades have further popularized the argument that the politically neutral pretentions of technoscience mask subtle uses of power, particularly in connection with environmental dangers. Basing any program of political change on science, and then even going so far as to present it as merely technical - like the technocrats do - can thus not be seen as politically neutral or innocent (Scoones et al. 2015). What I shall suggest, however, is that with its ideal commitment to disinterestedness, perpetual critique, and openness, scientific discourse is a way that activists can pursue degrowth projects without threatening social and political peace or, indeed, risking 
outright dismissal. ${ }^{10}$ Science also provides a more hopeful shared language than economics, which has always come with clear ideological trappings and been linked to party politics.

Similar features have also allowed countercultural science critics around the world to quite routinely metamorphose from trouble-makers to heroic pioneers of important environmental knowledge (Cohen and Ottinger 2011; Jamison 2001; Martinez-Alier et al. 2014). This historical fact is important for understanding shifts in environmental thought and policy but it also explains why countercultural critics of industrial modernity have so often involved students and young professionals, particularly in fields such as architecture, design and art. Here the comparison with the 1960s is illuminating. Importantly, there is a context-specific history we can draw on to appreciate the continuing salience of scientific discourse in Helsinki.

\section{Suomenlinna 1968}

In July 1968, a seminar series was held on the historic fortress island of Suomenlinna in Helsinki under the title, Industry, environment and product design. The opening address by the technologist and academically acclaimed energy-expert Erkki Laurila (who was also an early proponent of nuclear power) made reference to the prevailing situation where technological advances and industrialization, though welcome in principle, were endangering people and the environment. Participants - designers, engineers and architects and educators in these fields - were invited to steer their work to address this predicament. The event was presented in part as a conversation about Finland's economic growth, but much of its contents, and the way it is recalled today by those who participated, was about how to design better futures without producing unintended, adverse consequences. I have interviewed four men who were there, all born in the 1930s or 1940s, some of whom were instigators of the event. ${ }^{11}$ Besides seeking context for today's activism, my interest in it has been aroused also because it seems that few have researched its cultural or personal dimensions, preferring instead to concentrate on its intellectual and professional content.

What took place in July 1968 was a series of talks and workshops where local and international designers celebrated Nordic social virtues and promoted ethical design. The event was retroactively branded Helsinki Design Lab (HDL), an episode I return to below. The Suomenlinna meetings were proposed by a number of young professionals and about-to-graduate students of design and architecture. They were supported institutionally and financially by establishment figures in education and government, notably the recently established Finnish Innovation Fund Sitra. ${ }^{12}$ There was politics here, for among the business and technological elites, many saw an urgent need to overhaul architectural and design education and shift the focus away from an older preoccupation with beauty, craft and frivolity. Developing more serious pedagogy in industrial design was for them a national imperative. In 1967 Finland celebrated half a century of independence (from Russia in 1917), and that milestone presented an opportunity to do what was needed to join the front runners of technological - and economic - progress. That the wider project of harnessing technology for the national good had considerable success (until recently at least) is one reason that the idea of scientific and technical knowledge retains a non-partisan status in Finland and serves as a source of apolitical common ground for national audiences (Berglund 2007). Disagreement over details and facts, of course, abounds.

Also in 1968, the international design Triennale in Milan had been the focus of anti-consumerist protest, and although the Suomenlinna seminar is often invoked as part of a general anti-establishment repertoire and thus aligned with social critique (Clarke 2013), neither in a sartorial nor an intellectual sense did it mimic the drop-out eco-utopianism of southern Europe's or America's countercultures. Nor did it prefigure the kind of decentralized and self-organizing practices aimed at transitioning to degrowth that we see today. Whatever its funders were aiming for, the seminar's international speakers started from

\footnotetext{
${ }^{10}$ The strong cleavages between putative social "bubbles" whether pink, red, green or racist and even anti-anti-growth do not, as yet at least, suggest that scientific authority is eroding, although the respect and budgets accorded to higher education have been considerably diminished in just a couple of years.

${ }^{11}$ Interviews in 2015 with: Juhani Pallasmaa, Tom Simons, Yrjö Sotamaa, Tapani Launis, Jukka Noponen (Sitra). Further documentation at http://www.helsinkidesignlab.org. [accessed September 16 2016]

${ }^{12}$ Run autonomously under parliamentary oversight.
} 
recognizing that economic growth and consumerism were harming society and the planet. In a war-weary Finland that had been late to urbanize and adopt consumer lifestyles and motorcars, and where forestry still dominated the economy, simply to talk about curtailing economic growth was truly radical.

One of the guest speakers, vividly recalled 50 years later by my interviewees, was Richard Buckminster Fuller. He was one of the most influential yet most baffling inspirations also for the young American eco-utopians wanting to try to redesign their world (Castillo 2015; Sadler 2012). His long(winded) lectures on the radical technical innovation needed to avert major looming worldwide problems articulated, as my interviewees put is, intuitions they themselves had yet to put into words. Above all, he appears to have spelled out how the "global environment" as a whole was under threat. But at the same time as anticipating apocalypse, Fuller was developing a vision of a science of design to make the world better, based on inventorying the world's resources. His work also offered a promise - which many of the young participants ardently believed in - of achieving the technological prowess to manage the threat. As Fuller became an icon of the countercultural and hippie movements (Turner 2009), his message became aligned with the pioneering computer simulations by the Club of Rome and the publication, in 1972 of the ecoscientific global manifesto, The limits to growth. These approaches to global environmental problems have not always been popular among social scientists, in fact, as a recent volume titled The politics of green transformation (Scoones et al. 2015) shows, they have tended to be technocratic, racist and/or naïve and have largely ignored questions of justice. Often underpinned by crudely ethnocentric values and concepts of ethics, property and human nature, they have promoted technical and commercial solutions to fix politicoeconomic troubles. In Helsinki, as in his writings, like World design science decade 1965-1975 Fuller was forceful in promoting technical innovation over politics (Fuller and Hale 1963).

Another speaker at the seminar was Victor Papanek. He is less easy to dismiss as a mouthpiece of Western hubris than the maverick Fuller. Papanek's work is also being rediscovered as degrowth thinking takes hold. His Design for the real world became a classic of design writing, published first in Swedish in 1970 and translated into 23 languages. It featured several applications of design prowess for poor countries and vulnerable people, it dismissed most of the design profession as destructive and expressed scorn for the marketing of mainstream design. Many of the seminar participants were impressed by Papanek's socially useful applications of design skill - such as the radio receiver for use by illiterate villagers in poor countries made from a juice-can. ${ }^{13}$

The seminar has caught the interest of anthropologist Alison Clarke (2013), and there is also an excellent recent Masters thesis on it, written by Kaisu Savola for London's Royal College of Art. She also emphasizes the "scientification" of design and contextualizes it in the student radicalism unfolding around it. As Savola writes, in "the face of post-war social and economic challenges, designing was to evolve into 'a problem-solving and decision-making activity', including experts from a range of disciplines as different as psychology, ergonomics, engineering, physiology and statistics" (2015: 72). In an echo of my interview findings, Savola describes how the seminar promoted trust in science, technology and communications theory, and belief in the untapped potential of architecture and design for the urgent task of building a better world.

It was not that American student radicalism was not important in Finland. My interviews made it clear that it was, and protest emerged at the time across the Nordic world much as elsewhere. Thus the seminar was part of a burst of radicalization that developed an internationalizing and globalizing agenda. Finnish youth were enthusiastic for what they could learn about campus culture and global fashions and discourses Viet Nam affected youth in Finland as well. The visual look of their protest was developed among other places in the radical student publication, \&SDO, published by the Scandinavian Design Students Organization and sold in Denmark, Sweden, Norway and Finland. The anger, psychedelic overtones and sometimes ill-mannered tone of the magazine was no doubt kin to a world-wide reaction to the aestheticization and sanitization of problematic social and ecological developments. However, the experiences and subjectivities of those who were young in the 1960s were of course fundamentally shaped by local political cultures. Just as Nordic (Scandinavia, Iceland, Finland) co-operation in economic and political

\footnotetext{
${ }^{13}$ The radio ran on "anything that will burn," used paraffin wax and a wick and received all stations. Papanek did not see this as a problem for places with only one broadcaster. See Papanek (2011 [1971]: 224-227).
} 
life was developing at government level, leading to impressions - justified and otherwise - of a peculiarly Nordic set of virtues, the culture of protest to which the Suomenlinna seminar belonged was also Nordic and even more, local. To the delight of many, Fuller and Papanek were both impressed by what they saw as the democratic and environmentally sane ways of organizing life that they found on their trips to Finland and the other Nordic countries.

In turn, those present whom I have interviewed were charmed by the force of rationality and science articulated by the international speakers (who included others too) ${ }^{14}$ Rather than turning their backs on the mass production, pre-fabrication and consumerist design culture that Papanek and American counterculturalists opposed, the young Finnish architects and designers present believed in technology's capacity to cure the ills that it had produced in the first place. Besides my interview materials, copious writings on these themes in contemporary publications testify to this tendency. It is thus easy to agree with Alison Clarke's contention that Papanek's activist design was formulated less in the context of North American anticonsumption cultural tendencies (2013: 165) than as part of the regionally specific political and technical conditions of post-war Northern Europe.

\section{Exploring variations of the good}

In 2009 the Finnish Fund for Innovation Sitra launched a new unit to develop design-inspired ways of addressing global problems and called it Helsinki Design Lab (HDL). The name was explicitly inspired, so the website announced, by Suomenlinna 1968. Indeed, such retroactive celebration of locally based design for good made sense. Interestingly, the person who was in charge of the unit during its existence until 2013, Jukka Noponen, was rather vague about the details of the 1968 seminar. It may be that the nominal attribution, and the fact that the materials about the seminar are now available on the website, simply resulted from savvy branding by two US-born employees of HDL. Still, in discussing my little project, Noponen insisted that there is an important arc from the techno-utopian late 1960s to our efforts today to move away from a disastrous "normal."

If reluctant to dwell on questions of politics characterized Suomenlinna 1968, it still features in Sitra's work. For an institution with a national remit, ${ }^{15}$ steering clear of potentially divisive political agendas is, however, unremarkable. What does seem surprising is that the tiny social movements whose practices flirt with degrowth and sometimes even promote it, also shy away from articulating or in some cases even accepting that at the heart of their activities is a political, society-altering, vision. I suggest that this reluctance to be political, in the 1960s and today, is grounded in a self-conception of inventiveness or resourcefulness that emerged historically with national political institutions. This view was also articulated with hindsight and some wistfulness in the interviews themselves.

From today's vantage point my interviewees actually saw the hopes they themselves had once had as naïve. One of them, the architect and prolific writer Juhani Pallasmaa, was known for some time as a particularly enthusiastic proponent of rationalism in the service of the social good. He told me that looking back on it, the 1960s were the last truly utopian era. He explained further that it had been stamped by a widespread belief in rationality and the world-improving potential of industrial development. For him Suomenlinna was, among other things, a manifestation of a belief in technology that has since dwindled but that still informs his own writing and talk. Politics did eventually come in, he told me, and the event made him realize that all design has a political dimension. Until then design for him had been about naïve heroworship. Echoing others, he said his generation "turned aggressively against the world-famous [Finnish] designers of the 1950s - who suddenly weren't valued at all."16 His narrative, and similar accounts by all my interviewees, indicates an awakening at once intellectual, political and moral.

\footnotetext{
${ }^{14}$ Hans Palmstierna, Björn Tell, G. Ljunberg, Jan Kronlund, Folke Blomberg and Bob Fenney from Sweden, G.D. Whitehead from the UK, Christopher Alexander from the USA among others (http://1968.helsinkidesignlab.org/program.php).

${ }^{15}$ http://www.sitra.fi/en/about-sitra [accessed September 16, 2016]

${ }^{16}$ Like many of his contemporaries, Pallasmaa worked for a while in the early 1970s in poor parts of the world where what had remained abstract in 1968 became concrete: the throughput of material with no benefits to anyone somehow became an unspoken element of his worldview.
} 
The setting for this identity-shaping experience was a conjuncture that was particular to its time and place: an economic upswing, a socio-demographic transition inflected simultaneously by post-war and Cold War projects. In the 1960s Finland was only just becoming urbanized. The heritage of architecture and design that Pallasmaa and his peers reacted against, had nonetheless managed to combine technological innovation with a symbolic repertoire full of nationalist overtones that invoked the country's pre-urban, closeto-nature, past. Against such a background, it becomes less surprising to see the angry-ish young men of 1968 embracing Fuller's and Papanek's technophile recipes for designing a better world with ecology and global poverty in mind. It even helps make sense of their enthusiasm for pre-fabrication and integrated systems of construction, things that today's critics rail against and that certainly do not fit the small-scale, counter-cultural and self-organizing ethos of 1960s "Hippie Modernism" either (Castillo 2015).

As much as they address uncertain and scary horizons of global scope, concerns about unsustainability always emerge and develop in local political settings. My argument here is therefore about political culture, about how as a member of a collective one accepts - is perhaps compelled to accept - rules of reasoning and deliberation. After all, to live a good life and to be a good person is to be part of a collective. The nation-state remains important here, a particular constituency that might be persuaded to join activist efforts. The activist's face-to-face (or elbow-to-elbow) experience, often steered by online communication, is more salient still, in being so emplaced and embodied. As such, tiny social movements offer moments of relief from the insistent complications, contradictions and discomforts of a world that makes no sense because we all know it is unsustainable. They create spaces for developing alternative identities and with them and through them, alternative technologies and habits. Yet besides being emplaced and embodied, tiny social movements today are sustained by important abstractions. Rational or scientific discourse, as a contrast to "politics," is such an abstraction. For some, the concept of degrowth, whether vague or precise and sophisticated, is another.

Undeniably degrowth is drawing growing interest and feeding the science-based reasonableness of Helsinki's tiny social movements, but parallel to this a tragedy may be unfolding as government programs cut off support to universities and science. In this respect, unlike the reformers of the late 1960s, today's Finnish elites may just be copying international trends and bringing their unsustainable and undemocratic consequences to Helsinki too (Brown 2015). But my hunch is that in the process, the professional, scientifically literate creatives will be only more drawn to practical activism, along with the myriad explorations and abstractions this entails.

\section{References}

Bergholm, T. and A. Bieler. 2013. Globalization and the erosion of the Nordic model: a Swedish-Finnish comparison. European Journal of Industrial Relations 19(1): 55-70.

Berglund, E. 2007. Information society Finnish-style. In J. Edwards, P. Harvey and P. Wade (eds.) Anthropology and science: epistemologies in practice. ASA Monographs 43. Oxford and New York: Berg.

Berglund, E. 2013. Design activism in Helsinki: notes from the World Design Capital 2012. Design and Culture 5(2): 195-214.

Boal, I., J. Stone, M.J. Watts and C. Winslow (eds.). 2012. West of Eden: communes and utopia in Northern California. Oakland: Retort/PM Press.

Botero, A., A. Paterson and J. Saad-Sulonen (eds.). 2012. Towards peer production in public services: cases from Finland. Helsinki: Aalto University Publication Series.

Boyer, B., J.W. Cook and M. Steinberg. 2011. In studio: recipes for systemic change. Helsinki: Sitra.

Brennan, T. 2000. Exhausting modernity: grounds for a new economy, London and New York: Routledge.

Brown, W. 2015. Undoing the demos: neoliberalism's stealth revolution. New York: Zone Books.

Castells, M. 1978. City, class, and power. New York: St. Martin's Press.

Castillo, G. 2015. Hippie modernism: how Bay Area design radicals tried to save the planet. Places Oct. 2015. 
Chatterton, P. and J. Pickerill. 2010. Everyday activism and transitions towards post-capitalist worlds. Transactions of the Institute of British Geographers NS 35: 475-490.

Cocco, G. and B. Szaniecki (eds.). 2015. Creative capitalism, multitudinous creativity: radicalities and alterities. Lanham: Rowman Littlefield/Lexington Books.

Demaria, F., F. Schneider, F. Sekulove and J. Martinez-Alier. 2013. What is de-growth? From an activist slogan to a social movement. Environmental Values 22: 191-215.

Demmer, U. and A. Hummel. 2017. Degrowth, anthropology, and activist research: the ontological politics of science. Journal of Political Ecology 24: 610-622.

Deriu, M. 2015. Conviviality. In D'Alisa, G; F. Demaria and G. Kallis (eds) Degrowth: a vocabulary for a new era. London: Routledge. Pp. 79-82.

Douglas, G. 2014. Do-It-Yourself urban design: the social practice of informal "improvement" through unauthorized alteration. City and Community 13(1): 5-25.

Escobar, A. 2012. Notes on the ontology of design. Unpublished manuscript.

Foster, J.B. 2011. Capitalism and degrowth: an impossibility theorem. Monthly Review 62(08).

Fuller, Buckminster R. and J. McHale. 1963. Phase 1, Document 1 World Design Science Decade 19651975. Carbondale: Southern Illinois University.

Goodbun, J., J. Till and D. Iossifova (eds.). 2012. Scarcity: architecture in an age of depleting resources architectural design. Architectural Design July 2012 / Wiley.

Gordon, A. 2008. Spaced out: radical environments of the psychedelic sixties, New York: Rizzoli International Publications.

Graeber, D. 2011. Consumption. Current Anthropology 52(4): 489-511.

Guthman, J. 2008. Neoliberalism and the making of food politics in California. Geoforum 39: 1171-1183.

Jamison, A. 2001. The making of green knowledge: environmental politics and cultural transformation. Cambridge: Cambridge University Press.

Kalliala, M. with J. Sutela and T. Toivonen. 2011. Solution 239-246 - Finland: the welfare game. Berlin: Sternberg Press.

Kohtala C. and A. Paterson. 2015. Oxygen for Töölönlahti. In E. Berglund and C. Kohtala (eds.) Uusi Helsinki? Det nya Helsingfors? Changing Helsinki? 11 views on a city unfolding. Helsinki: Nemo. Pp. 64-71.

Latouche, S. 2009 Farewell to growth, translated from the French Petit traité de la décroissance sereine [2007] by David Macey, Cambridge: Polity Press.

Manzini, E. 2015 Design, when everybody designs: an introduction to design for social innovation. Cambridge: MIT Press.

McClintock, N. 2014. Radical, reformist, and garden-variety neoliberal: coming to terms with urban agriculture's contradictions. Local Environment 19(2): 147-171.

Mouffe, C. 2013. Agonistics: thinking the world politically. London and New York: Verso.

Novy, J. and C. Colomb. 2013. Struggling for the right to the creative city in Berlin and Hamburg: new urban social movements, new "spaces of hope". International Journal of Urban and Regional Research 37(5): 1816-1838.

Papanek, V. 1971. Design for the real world: human ecology and social change. New York: Pantheon Books.

Pinder, D. 2005. Visions of the city: utopianism, power and politics in twentieth-century urbanism. New York: Routledge.

Rajan, R.S. and C.A.M. Duncan. 2013. Ecologies of hope: environment, technology and habitation - case studies from the intervenient middle. Journal of Political Ecology 20: 70-79.

Sadler, S. 2012. The dome and the shack: the dialectics of hippie enlightenment. In I. Boal, J. Stone, M.J. Watts and C. Winslow (eds.) West of Eden: communes and utopia in Northern California. Oakland: Retort/PM Press. 
Savola, K. 2015. When beauty is not enough to save the world: a short history of the Scandinavian Design Students' Organisation 1966-1969. MA Dissertation. London: RCA/V\&A History of Design Programme.

Scoones, I., M. Leach and P. Newell (eds.) 2015. The politics of green transformation. London and New York: Earthscan/Routledge.

Seppälä, P. 2012. Tiny social movements: experiences of social media based co-creation. In Botero, A., A. Paterson and J. Saad-Sulonen (eds.). Towards peer production in public services: cases from Finland. Helsinki: Aalto University Publication Series. Pp.62-75.

Swyngedouw, E. 2010. Apocalypse forever? Post-political populism and the spectre of climate change. Theory, Culture, Society 27(2-3): 213-232. Researchgate

Szaniecki, B. and G. Cocco. 2015. 'Introduction', in Cocco, G. and B, Szaniecki (eds) Creative capitalism, multitudinous creativity: radicalities and alterities, Lanham: Rowman Littlefield/Lexington Books. Pp. vii-xviii.

Taylor, B. 2013. From alterglobalization to Occupy Wall Street: neoanarchism and the new spirit of the left. City 17(6): 729-747. Academia

Thorpe, A. 2012. Architecture and design versus consumerism: how design activism confronts growth. London: Routledge.

Toivanen, T. and J. Venäläinen. 2015. Yhteisvaurauden uusi aika. In M. Jakonen and T. Silvasti (eds.) Talouden uudet muodot. Helsinki: Into.

Turner, F. 2005. Where the counterculture met the new economy: the WELL and the origins of virtual community. Technology and Culture 46(3): 485-512.

Turner, F. 2009. A technocrat for the counterculture. In H-Y. Chu and R.G. Trujillo (eds.) New views on R. Buckminster Fuller. Stanford University Press.

Ulvila, M. and J. Pasanen. 2010. Vihreä uusjako: fossiilikapitalismista vapauteen. Helsinki: Like.

Williams, G. 2008. Struggles for an alternative globalization: an ethnography of counterpower in Southern France. Hampshire: Ashgate.

Ylönen, V. 2015. The chameleon on the beach. E. Berglund and C. Kohtala (eds.) Uusi Helsinki? Det nya Helsingfors? Changing Helsinki? 11 views on a city unfolding. Helsinki: Nemo. Pp. 244-249. 